\title{
Glucagon-like Peptide-1 Measurement
}

National Cancer Institute

\section{Source}

National Cancer Institute. Glucagon-like Peptide-1 Measurement. NCI Thesaurus. Code C80183.

The determination of the amount of glucagon-like peptide-1 present in a sample. 